\title{
EXPLORING GENDER ON EFL LEARNERS' BELIEFS ABOUT LANGUAGE LEARNING
}

\author{
Hanna Sundari; Irfan Hadi; Nurhayati \\ Indraprasta, PGRI University \\ Jln. Nangka No. 58, Tanjung Barat, Jakarta Selatan \\ hanna.sundari@gmail.com
}

\begin{abstract}
Article aimed to describe language learners' belief system and to investigate how significance the language learners' beliefs are between them in language learning. Using both qualitative and quantitative approaches, this research took 111 female- and 32 male-first semester college-students majoring in English Education as respondents. The instrument was 34-item BALLI questionnaire designed by Horwitz. The findings of the research showed that females and males' language beliefs about language learning are mostly in similar fashion. The significant differences in responses were on the beliefs related to language and intelligence, enjoyment in practicing English, learning English-speaking cultures, having English-speaking friends, and motivation in learning English.
\end{abstract}

Keywords: language learning, language learning belief, gender

\begin{abstract}
ABSTRAK
Artikel menggambarkan sistem keyakinan berbahasa pembelajar dan mencari tahu seberapa signifikan perbedaan keyakinan berbahasa antara pembelajar pria dan wanita. Dengan pendekatan kualitatif dan kuantitatif, penelitian ini mengambil sampel 111 pembelajar wanita dan 32 pemelajar pria pada semester 1 mahasiswa program pendidikan bahasa Inggris. Instrumen penelitian adalah BALLI kuesioner yang dirancang oleh Horwits. Hasil penelitian menunjukkan bahwa keyakinan berbahasa baik pembelajar pria maupun wanita pada umumnya sama. Meskipun demikian, perbedaan yang signifikan tampak pada kaitan bahasa dan kecerdasan, kesenangan dalam berlatih bahasa Inggris, budaya bahasa Inggris, memiliki teman penutur asli, dan motivasi dalam belajar bahasa Inggris.
\end{abstract}

Kata kunci: pembelajaran bahasa, kepercayaan pembelajaran bahasa, gender 


\section{INTRODUCTION}

Learners' belief about language learning is considered as a significant factor to determine successful language learning, like many other factors. Schoenfeld (in Bernat \& Llyod, 2007:79) stated that one's belief systems, social cognitions, and metacognitions are a driving force for intellectual performance. Intellectual performance involves acquisition and learning second/foreign language. A study by Maftoon and Shakouri (2012) showed that there was certainly a relationship between the students' belief system and their choices of strategies.

Dealing with factors influencing language learning, gender differences, as one of sociocultural factors, has been observed in language use. Lakoff (in Coates, 2007: 62-63) drew attention to a wide range of gender differences in language use and argued that differences were directly related to the relative social power of male speaker and relative powerlessness of female speakers. Research by Moriam (2005) among Japanese and Bangladeshi learners showed that there were some differences speaking strategy used by either male or female learners.

Study in language learning belief and gender has also been conducted by some researchers. Research by Rieger (2008:37) investigated 61 students in secondary school in Budapest. The result showed that both gender and the target language significantly affect language learner's belief about language learning. With regard to gender, the only significant difference found was the perceived importance of practicing the target language with authentic written text.

In short, even though the studies related to language learning belief and gender have been done in many countries, it still has a plenty of improvement particularly for learners in Indonesia. This research is to describe and investigate language learners' belief system and gender among the college-students in Indonesia. Furthermore, this research is to ascertain if there were any significant differences in responses among the students.

In language acquisition and learning, belief has different definitions. According to the mainstream approach, belief is,"Cognitive entities in learner's mind; belief is as stable, statable, and fallible." Meanwhile, the discursive approach viewed belief as, "Socially constructed and variable from one person to another as well as from context to another" (Maftoon \& Shakouri, 2013:42). Understanding learner's belief is important. Insightful belief about language learning process may end up with successful learning. Moreover, belief determines learner's learning strategies, classroom anxiety and cognitive performance (Mesri, 2012:99). For instance, a student who thinks that learning language is mostly about grammar conventions will spend much time and effort on mastering it. On the other hand, a student who believes that special ability is necessary to learn foreign language, but $\mathrm{s} /$ he does not possess it, may start learning with negative expectation.

Second/foreign language researches have shown that beliefs are quite stable within the learner, strongly held, and resistant to change (Mesri, 2012). On the contrary, Maftoon and Shaouri (2013:43) wrote since language acquisition is as part of knowledge through discourse, the knowledge means partly repeated words and thought formulated by others. As a result, beliefs reflect personal views. Horwitz (in Fujiwara, 2011:88) categorized language learning belief onto the following five themes: (1) foreign language aptitude, (2) the difficulty of language learning, (3) the nature of language learning, (4) learning and communicative strategies, and (5) motivations and expectations. Horwitz constructed 34 items of language learning questionnaire, namely BALLI questionnaire.

The relationship between gender and language use has been investigated for years. Sociolinguists distinguish between sex - a biological term - and gender, the term used to describe socially constructed categories based on sex (Coates, 2007). Then it has two terms of gender, masculine and feminine. Gender identity is seen as a social construct rather than as a "given" social category. As West and Zimmerman (1987, in Coates, 2007:66) eloquently put it, speakers should be seen as "doing gender" rather than statistically "being" a particular gender. The understanding that gender is a social and cultural construction became widespread in early 1990s. Differ from that, gender now is conceptualized as something that is "done." It is never static but it produced actively and in interaction with others every day of lives (Coates, 2007:66). Gender now is constructed locally and interacted with race, class, sexuality and age.

Numerous studies in the issues of language learning belief and gender have been done for years. Research by Bernat and Lloyd (2007) has been significantly influenced for next study about related issues. They found that overall males and females held similar belief about language learning. Males and females seem to respond similar fashion in the term of (1) foreign language aptitude, (2) difficulty in learning a language, (3) the nature of language learning, (4) strategies in learning and communication, and (5) motivations and expectations. Meanwhile male and female seem to differ significantly in their beliefs that multi-linguals are very intelligent, with more females agreeing with the statement. They marginally differ in their enjoyment of practicing English with Australians, with women enjoying it less.

In additional to Bernat and Llyod's research findings (2007), it was found similar opinions between females and males in almost all terms. Most respondents agreed that children learn a foreign language easier than adult; that some people have a special to learn it and everyone can learn to speak it. Moreover, they also believed that some languages are easier than others; that it is necessary to learn about English speaking cultures and the best way to learn English is in English speaking country. Furthermore, they thought that it is important to speak English with excellent pronunciation and practicing and repeating it a lot as well as they would like to learn and speak English very well. The survey also showed the respondents find English medium. Then, if spend 1 hour/ day, they think it would take around 3 to 5 years to speak the language very well; some believed it needs more than 1 hour/day.

On the other hand, still on Bernat and Llyod's research findings (2007), respondents disagreed with the statement related to Learning how to translate from own 
language as the most important part of learning. Besides, they disagreed that you shouldn't say anything in English until you can say it. The beliefs which differ significantly between males and females are that multi-linguals are intelligent and it is enjoyment to practice English with native speakers.

Findings of a study by Rieger (2009) on Hungarian EFL learners' beliefs about language learning showed that they generally agree with the statements given. They believe children are easier to learn foreign language and some people have special ability on learning it. They also agree that some languages are easier, reading and writing English are easier that speaking and understanding it as well as best way to learn it is in English-speaking country and learning a new words and excellent pronunciation are important. The respondents seem English medium; as a result, they, if spending 1 hour/day, would take 3 to 5 years to speak it very well. The study by Rieger also found that the respondents disagree that people who are good at math are not good at learning language. They do not believe that women are better language learners. They do not think that you shouldn't say anything until you can say it correctly. For motivation, in fact, Hungarian EFL learners do not find learning English to get to know native speakers better. However, it is to have better job opportunities.

In 2011, Fujiwara (2011) recruited 542 state university students in Bangkok, Thailand to be investigated their beliefs about language learning related to dimensional structure and cultural variations. The result showed that five-factor structure was identified for the language learning belief. They are (1) learning and communication strategies (2) important aspects in language learning, (3) expectation and difficulty of learning language, (4) nature and aptitude of language learning, and (5) difficulty and ability in language learning.

Furthermore, Mesri (2012) explored among 90 male and female Iranian university students ages ranged from 18-31. The research has proved statistically that there is no significant effect on gender on learners' beliefs to learn English. There was also no significant difference between their beliefs and gender.

Finally, research by Maftoon and Shakouri (2013) analyzed about relationship between learner's belief system and the choice of language learning strategies among 39 males and 41 females college-students from Islamic Azad University, Iran. The findings concluded that the students had a general positive belief about learning language; mostly in their motivations and expectations. However, language learning strategies were found to be weakly correlated with beliefs. As a result, the more students used a particular strategy group, the less positive belief they held about language learning.

The studies about language belief as mentioned above have been conducted in many countries such as Australia, Hungarian, Iran and Thailand. The result showed various results over countries. This may indicate that language learner's belief is related to not only personal views and opinion but also age, culture, and region.

\section{METHOD}

The respondents of the research were 143 fresh college-students in Indraprasta PGRI University academic year 2013/2014. They were at first semester in English Education program. They consisted of 32 male collegestudents and 111 female college students.

The survey instrument consisted of 34 items from the "Beliefs about Language Learning Inventory" (BALLI) designed by Horwitz (1987) on a five-point Likert Scale. The original version of BALLI contained 34 items questionnaire. This instrument is widely used in much research (Bernat \& Llyod, 2007; Fujiwara, 2011). The BALLI measures language learning beliefs in five areas/dimensional themes is as follows:foreign language aptitude, the difficulty of language learning, the nature of language learning, and learning and communicative strategies.

At the second phase, to assess whether the difference was significant or not between female and male college students' language learning belief, the data from BALLI would be tested quantitatively using WilcoxonMann-Whitney test (Uji Mann-Whitney U, 2009; Uji Wilcoxon, 2010) helped by SPSS 21.0 Version.

\section{RESULTS AND DISCUSSION}

\section{Foreign Language Aptitude}

This dimensional theme, foreign language aptitude, assesses respondents' perceptions of language learning related to age, ability, and gender. From all nine statements, two statements differed significantly in responses between female and male college students. The responses of Statement $1-9$ can be seen in Figure 1.

Responses for the first statement "It is easier for children to learn a foreign language" on the chart above showed that $63 \%$ female-students and $12.5 \%$ malestudents agree that children are easier to learn foreign language. Even 17\% female- and $62.5 \%$ male-students strongly agree to the statement given. In short, a majority $(79 \%)$ believed that children learn foreign language easier. However, there was no significant difference in responses between male- and female-students (p-values $1.000<$ $0.05)$.

The second statement stated that "Some people have a special ability for learning foreign languages." A majority (79\%) agrees and strongly agrees that some people have special ability in learning foreign languages. Nonetheless, $14.6 \%$ college-students fell into "neutral." In fact, with p-values $0.206(>0.05)$, there was not any significant difference in responses between female and male students.

Responses in the third statement "People from my country are good at learning foreign languages" went to variety of answers. $15 \%$ respondent disagreed that Indonesian people are good at learning foreign language. A bigger percentage (83\%) fell into neutral options. On the contrary, the small portion (38\%) agreed with the statement. Wilcoxon-Mann-Whitney tests showed no significant difference responses between females and males, p-values $0.388(>0.05)$.

On the fourth statement "it is easier for someone who already speaks a foreign language to learn another one, " participants responded variously. A small percentage (18\%) did not agree; whereas, a majority (64\%) believed that one can learn another foreign language. Meanwhile, 
another $24 \%$ did not decide. Moreover, with p-values 0.602 ( $>0.05)$, there was no significant difference responses between females and males.

The chart on statement 5 "people who are good at math or science are not good at learning foreign languages" showed that most participants (58\%) disagreed. However, a sizeable portion $(29 \%)$ neither agreed nor disagreed that people who are good at math and science are good at learning foreign language. The rest $(13 \%)$ agreed with the statement. With p-values 0.099 ( $>0.05)$, female and male responses did not differ significantly on the item.

With p-values $0.487(>0.05)$, there was no significant difference responses between females and males on sixth statement "I have a special ability for learning foreign languages." Only a few students (5\%) agreed they do not believe that they have special ability. A sizeable portion (40\%) neither agreed nor disagreed. Majority students (78\%) believed that they have special ability in learning foreign languages.

Responses on statement 7 "women are better than men at learning languages" showed that a sizeable portion (38\%) agreed; on the other hand, the other $(38 \%)$ disagreed with the statement. The rest $(24 \%)$ did not decide who better learner is. with p-values $0.000(<$ 0.05), Wilcoxon-Mann-Whitney test scored significant difference in responses between females and males. It indicates that female students are more likely than males to believe women are better language learners than men.

Furthermore, item 8 stated "people who speak more than one language are very intelligent" showed a vast majority (85\%) agreed. Meanwhile, only $13 \%$ neither agreed nor disagreed. In contrast, a very small portion $(6 \%)$ did not believe that multi-lingual people are intelligent. Wilcoxon-Mann-Whitey test, with p-values $0.008(<0.05)$, showed that there was any significant difference in response between females and males. This means that they are not in the same opinion where females slightly more likely believe than males that multi-lingual people are intelligent.

On item 9 stated "Everyone can learn to speak a foreign language", the largest percentage of participants $(92 \%)$ agreed with the statement. Only small portion $(6 \%)$ neither agreed nor disagreed. Moreover, p-values scored $0.07(>0.05)$ resulted in no significant difference in responses between females and males.
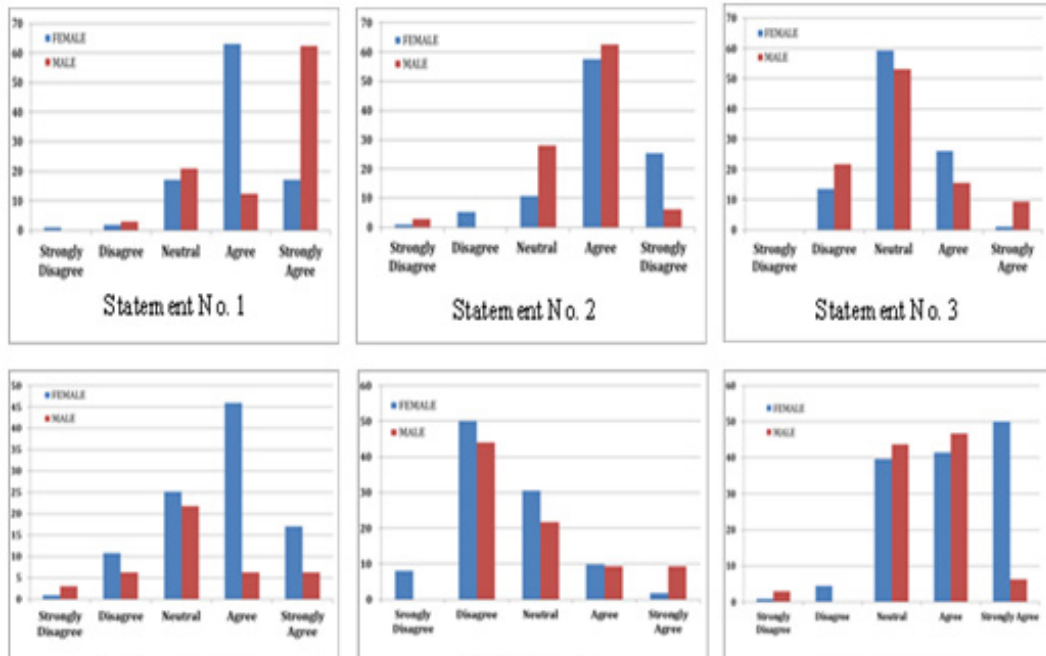

Statement No. 4

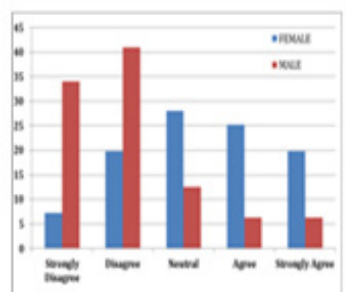

Statement $\mathrm{N}_{0 .} 7$
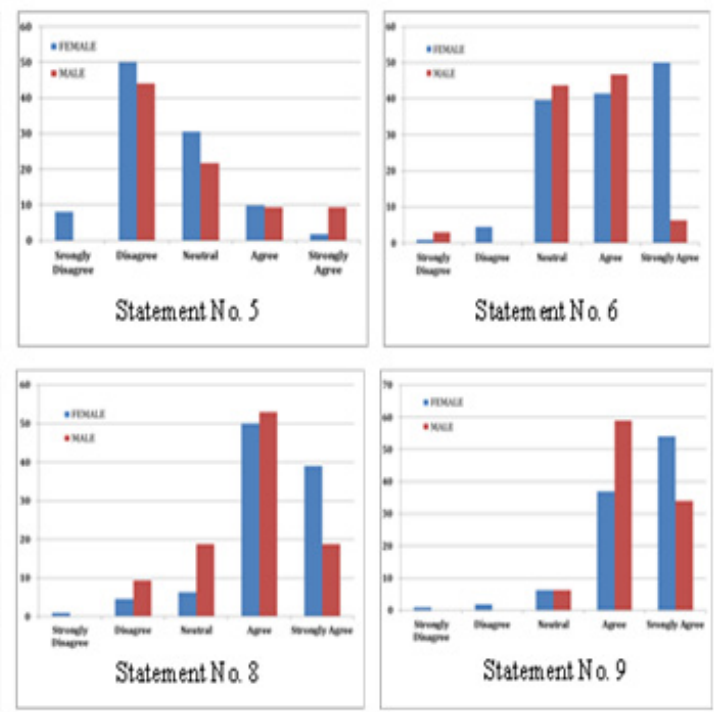

Figure 1 Charts of Statement 1-9 Responses

\section{The Difficulty in Language Learning}

The second dimensional theme, difficulty in language learning, explores students' perception of language learning dealing with how difficult English language is and which skill they consider more difficult. Besides, it also yields their perception on how long one can speak English well. The responses of statement 10-12 can be seen in Figure 2.
First of all, item 10 stated "Some languages are easier than others". The chart (Figure 2) showed that only a very few students $(2 \%)$ disagreed with the statement. However, a significant portion (64\%) of participants believed that some languages are easier. Yet, a sizeable percentage $(36 \%)$ did not decide whether they agreed or not. From Wilcoxon-Mann-Whitney test, p-values scored $0.952(>0.05)$. This means no significant difference in responses between females and males. 
Responses for item 11"It is easier to speak than understand a foreign language" showed variety in percentages. $18.8 \%$ of respondents disagreed that speaking is easier than understanding a foreign language. While a sizeable portion ( $43 \%$ ) felt speaking easier. However, $38 \%$ of them did not decide if speaking is easier than understanding a foreign language. In fact, there was no significant difference in responses between females and males due to $\mathrm{p}$-values $0.487(>0.05)$.
For item 12, the statement was "It is easier to read and write English than to speak and understand it". A majority of respondents (54\%) agreed with the statement. In contrast, a small percentage (13\%) disagreed. Yet, a sizeable portion $(33 \%)$ of them did not decide whether reading and writing English is easier than speaking and understanding. With p-values 0.321 ( $>0.05)$, responses did not differ significantly between females and males.

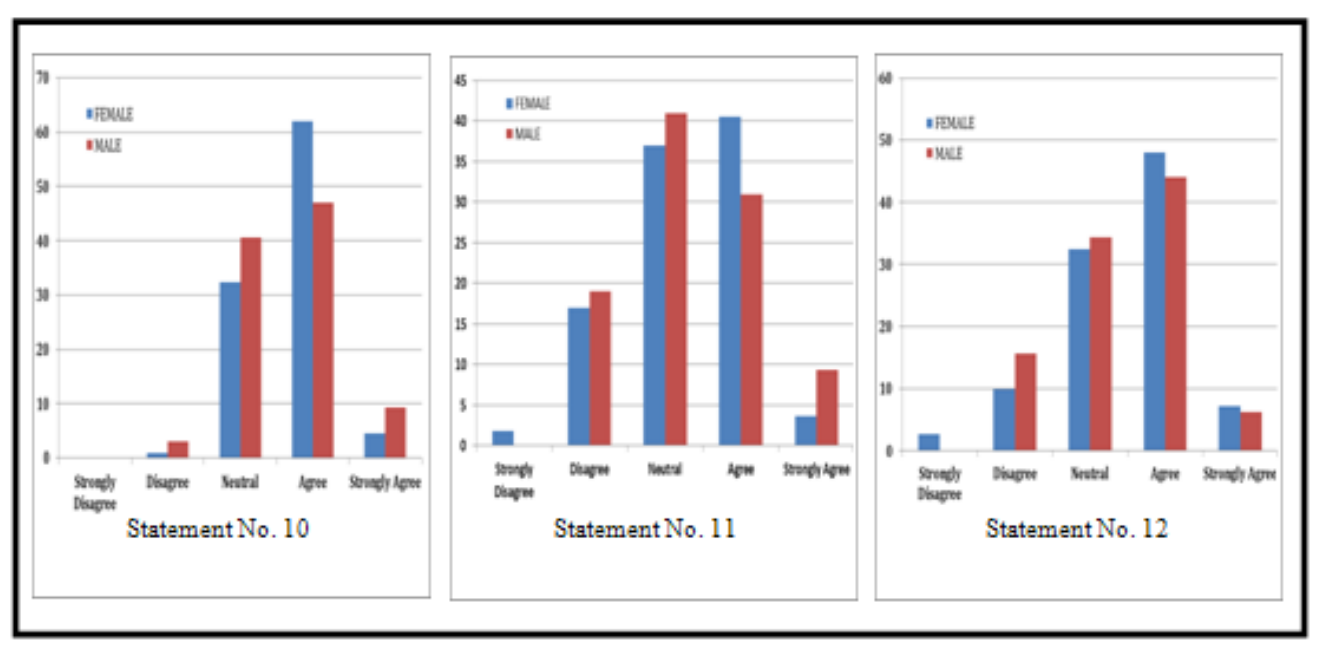

Figure 2 Charts of Statement 10-12 Responses

Two items - named item 33 and 34-were on the last position on the questionnaire because of different item categories. Nonetheless, they were included in this theme (the difficulty of language learning). The responses of statements 33-34 can be seen in Figure 3.

Responses for item 33 "The English language is: very difficult, difficult, medium, difficult, easy, very easy" showed that most respondents $(73 \%)$ found that English medium difficulty. A sizeable portion (16\%) thought English easy; yet, the rest (10\%) believe it difficult. In fact, p-value scored 0.782 ; so that, there was no significant difference in responses between females and males.
The last item on this theme, item 34 stated "If someone spent 1 hour/day learning a language, how long would it take them to speak the language very well?". The largest portion $(48 \%)$ of respondents thought that if someone spent 1 hour/day learning a language, s/he would take 1 to 2 years to speak it very well. A significant percentage $(33 \%)$ of respondents even believed that $\mathrm{s} /$ he only needed less than 1 year. Moreover, the small percentage $(15 \%)$ of respondents thought it would take little longer, 3 to 5 years. With p-value $0.283(>0.05)$, there was no significant difference in responses between females and males.

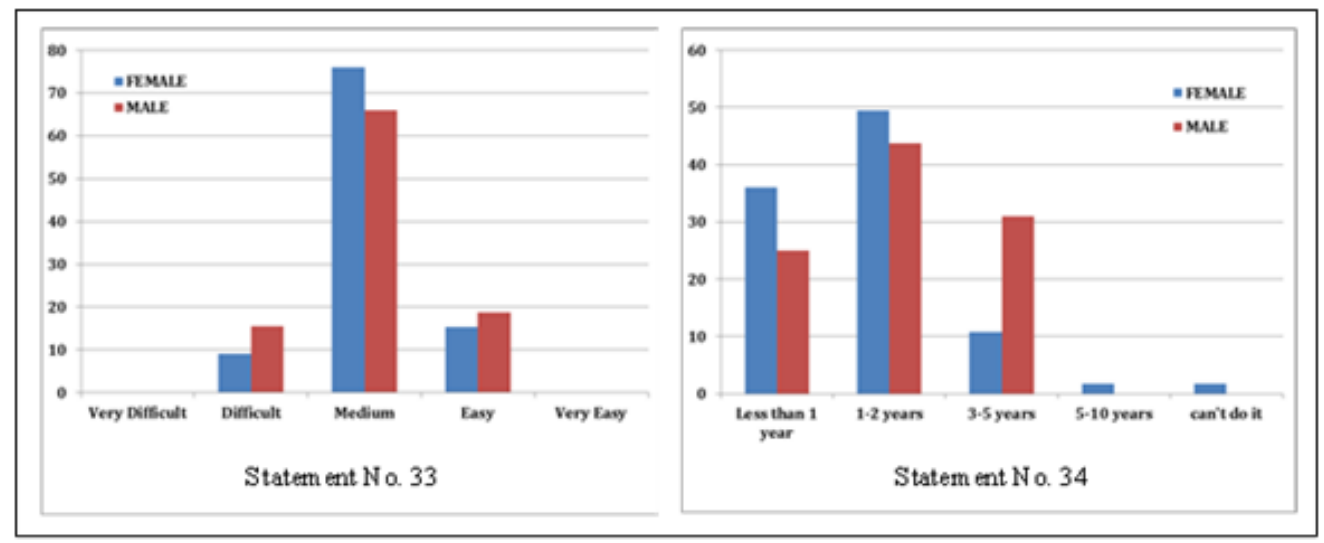

Figure 3 Charts of Statement $33 \neg-34$ Responses 


\section{Nature of Language Learning}

The nature of language learning elaborates learners' perception about the most important part of learning a foreign language: vocabulary, grammar, and translation. It also figures out English speaking country and cultures. The results are displayed on the bar charts in Figure 4.

Responses for item 13 stated "It is necessary to learn about English speaking cultures to speak English" were fairly spread over the response categories. The largest percentage of respondents $(46 \%)$ disagreed with the statement. A significant portion $(30 \%)$ of them neither agreed nor disagreed to learn English cultures. Meanwhile, the rest (24\%) believed that it is necessary to learn cultures when learning English. From WilcoxonMann-Whitney test, mean rank of women (8.33) was lower than men $(15.63)$ with p-values $0.017(<0.05)$. This indicates that females are more likely than men to disagree it is necessary to learn about English speaking cultures to speak English.

On item 14 stated "It is best to learn English in an English speaking country", the participants responded variously in all categories. The smallest percentage (18\%) of responses neither agreed nor disagreed. Meanwhile, a sizeable portion $(36 \%)$ disagreed that best way to learn English is in an English speaking country. A majority (46\%) thought that learning English in its speaking country is best way. Yet, there was no significant difference in responses between females and males, with p-values $0.242(>0.05)$.

In additional to the items above, item 15 stated

"The most important part of learning a foreign is learning a new word". A vast majority (86\%) of respondents agreed that learning a new word is the most important part, while $9 \%$ of neutral option and $5 \%$ of disagreement. With p-values 0.017 , there was any significant difference in response between females and males because mean rank of women scored 8.33 lower than men, 15.63. It means women are more likely to believe learning vocabulary is the most important in learning language.

Responses for item 16 stated "The most important part of learning a foreign language is learning grammar" showed that most respondents $(76 \%)$ agreed with the statement. On the hand, only small portion $(8 \%)$ of them disagreed that grammar is the most important part in language learning. The rest (16\%) felt into neutral option. Then, with p-values $0.340(>0.05)$, there was no significant difference in responses between females and males.

Furthermore, statement 17 stated that "Learning $a$ foreign language is different than learning other academic subjects". Most respondents (73\%) agreed with the statement. However, a sizeable portion (22\%) disagreed that learning foreign language is different than learning other subjects. Then, with p-values $0.729(>0.05)$, there was no significant difference in responses between females and males.

On statement 18 stated "the most important part of learning English is learning how to translate from my own language", a vast majority (74\%) of respondents agreed. However, a sizeable portion $(22 \%)$ thought that translating from own language is not important part in learning English. With p-values 1.000 (> 0.05), there was no significant difference in responses between females and males.

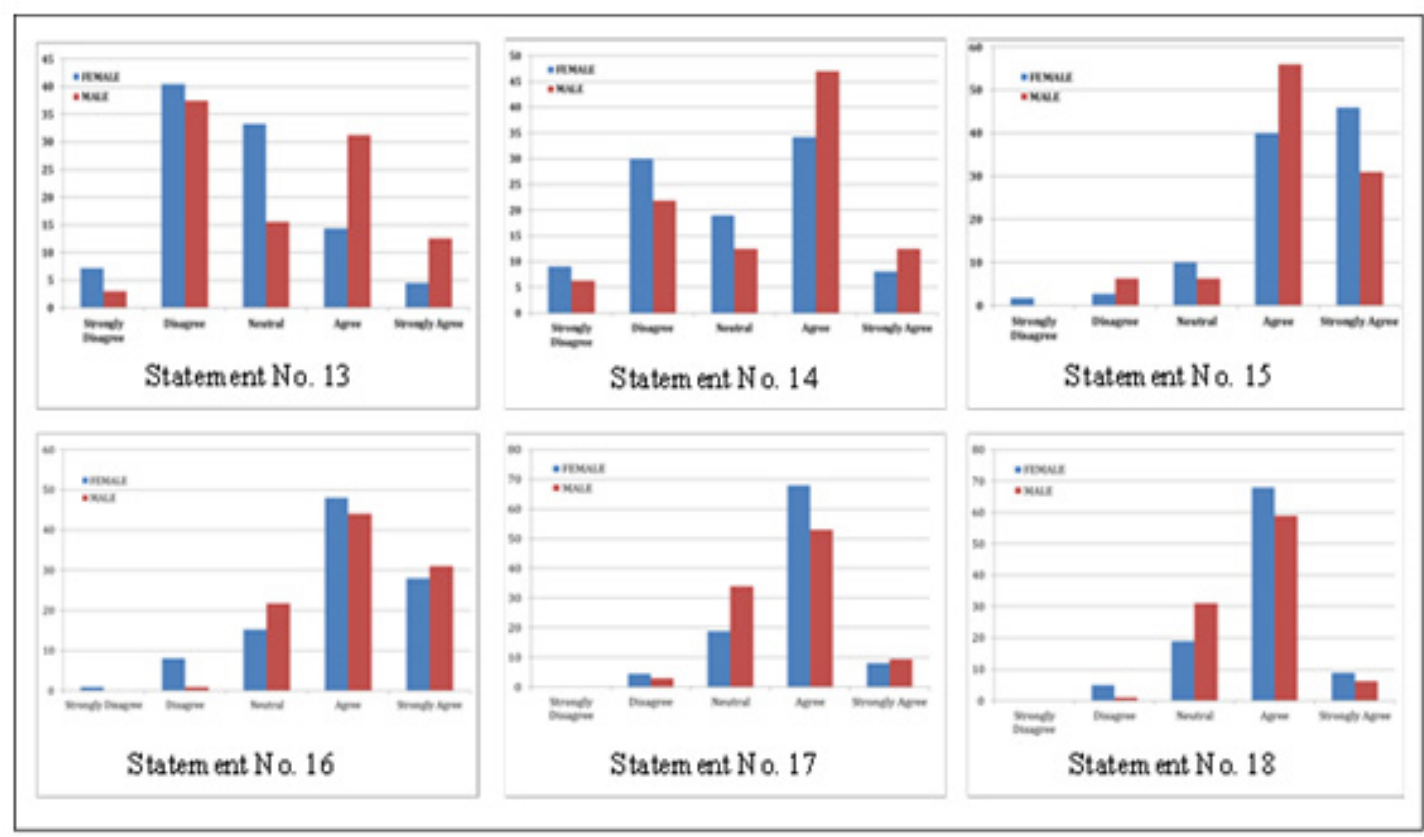

Figure 4 Charts of Statement 13-18 Responses 


\section{Learning and Communication Strategies}

The fourth dimensional theme of language learning belief, as learning and communication strategies, assesses learners' opinion on pronunciation, practicing English, making mistakes and using media. The research findings are presented below and the responses of statement 19-26 can be seen in Figure 5.

Firstly, item 19 stated "It is important to speak English with an excellent pronunciation". Most respondents (79\%) agreed with the statement. Meanwhile, a sizeable portion (16\%) did not decide whether excellent pronunciation is important to speak English or not. With p-values $0.289(>0.05)$, there was no significant difference in responses between females and males.

Responses for item 20 "you shouldn't say anything in English until you can say it correctly" showed most respondents $(66 \%)$ disagreed with the statement. The small percentage $(17 \%)$ of them believed that you should say anything in English correctly. The other (17\%) neither agreed nor disagreed. Besides, there was no significant difference in responses between females and males due to p-values 0.901 (>0.05).

To continue the items above, item 21 stated "I enjoy practicing English with the native speakers I meet”. The largest percentage (52\%) of respondents agreed with the statement. The smaller portion (38\%) went to neutral option. In addition, Wilcoxon-Mann-Whitney test showed mean rank of women (9.00) was lower than mean rank of men (11.14). Meanwhile, p-value scored $0.04(<0.05)$. It indicates that there was any significant difference in responses between females and males where females are more likely than men to enjoy practicing English with native speakers.

Responses for item 22 stated "It's OK to guess if you don't know a word in English" showed variety in all categories. The biggest percentage $(35 \%)$ of respondents agreed with the statement. In contrast, a sizeable portion
$(34 \%)$ thought that it is not OK to guess a word. The rest $(31 \%)$ did not decide whether it is OK or not to guess a word. With p-values $0.564(>0.05)$, there was no significant difference in response between females and males.

Moreover, item 23 stated that "It is important to repeat and practice a lot". An overwhelming majority of respondents $(90 \%)$ agreed and strongly agreed with the statement. Also, with p-values $0.060(>0.05)$, there was no significant difference. As a result, responses between females and males were in the similar fashion.

Responses for item 24 stated "I feel shy speaking English with other people" showed that most respondents $(59 \%)$ disagreed with the statement. Meanwhile, a sizeable percentage (20\%) of them did not decide whether they felt shy speaking English or not. In fact, with p-value 0.055 $(>0.05)$, there was no significant difference in responses between females and males.

On item 25 stated "If beginning students are allowed to make mistakes in English, it will be difficult for them to speak correctly later on", responses were spread over the response categories. The largest percentage (43\%) of respondents disagreed with the statement. Meanwhile, a sizeable portion $(24 \%)$ neither agreed nor disagreed. The rest $(32 \%)$ believed that making mistake make the leaners difficult to speak correctly. Then, there was no significant difference in responses between females and males, with p-value $0.102(>0.05)$.

The last item on this theme, the item 26 stated "It is important to practice with cassettes/tapes or CD rooms". Most respondents (71\%) agreed with the statement. Meanwhile, a smaller percentage $(22 \%)$ of them did not believe that cassettes/tapes or $\mathrm{CD}$ rooms important in practicing English. With p-value $0.191(>0.05)$, there was no significant difference in responses between females and males.

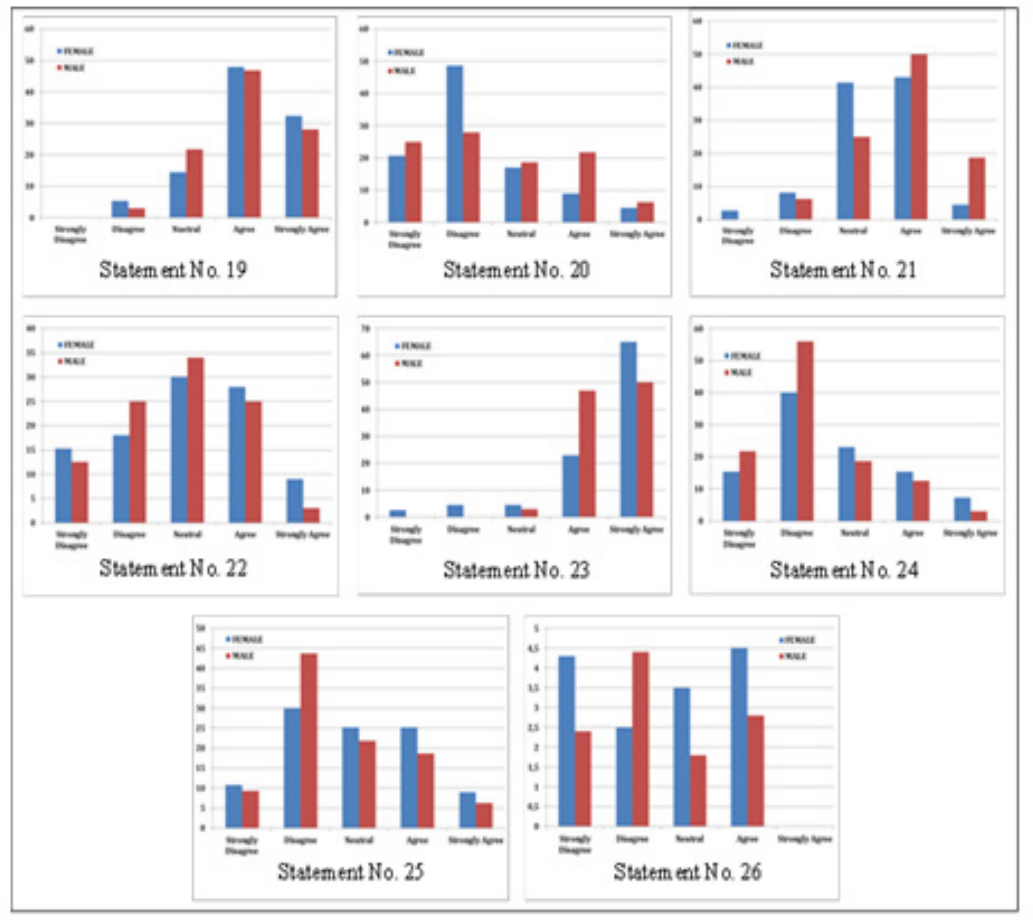

Figure 5 Charts of Statement 19-26 Responses 


\section{Motivation and Expectation}

Motivation and expectations, the last dimensional theme on language leaning belief, explores whether respondents will learn English well or not and its benefits. Moreover, it figures out respondents' opinions about English-speaking friends/native speaker. The results are presented below and the responses of statement 27-32 can be seen in Figure 6.

Dealing with motivation to learn English, item 27 stated "I believe I will learn to speak English very well." An overwhelming majority (94\%) of respondents agreed with the statement. It indicates that they have high motivation to learn speaking English very well. With p-value 0.032, responses between females and males differed significantly. Then, mean rank of women (8.50) was lower than mean rank of men (11.36). This means females are more likely than men to learn speaking English very well.

Secondly, with p-value 0.706, item 28 "People in my country feel that it is important to speak English", showed that there was no significant difference in responses between females and males. Most respondents $(82 \%)$ agreed with the statement. While, a sizeable portion $(16 \%)$ of respondents neither agreed nor agreed; the rest $(2 \%)$ disagreed that people in Indonesia feel that it is important to speak English.

Responses for item 29 stated "I would like to learn English so that I can get to know native speakers better" showed a majority (73\%) of respondents agreed with the statement. However, significant portion (24) did not believe that they learn English to get to know native speakers better. In fact, there was no significant difference in responses between females and males, p-value 0.268 $(>0.05)$.

On item 30 stated "If I learn to speak English very well, I will have a better job opportunities", it resulted in vast majority ( $86 \%$ ) of respondents' agreement. They believed that good competence in English will give them better jobs. Meanwhile, a sizeable percentage (12\%) neither agreed nor disagreed. With p-value 0.320 , there was no significant difference in responses between females and males.

Furthermore, item 31 stated "I want to learn to speak English very well”. An overwhelming majority $(97 \%)$ of respondents highly motivated to learn speaking English. With p-value 0.305 , there was no significant difference in responses between females and males.

The last item on this theme stated "I would like to have English-Speaking friends." The large majority $(88 \%)$ of respondents wanted to have English-speaking friends. The small portion $(9 \%)$ did not decide whether they wanted to have them or not. This item, with p-value 0.025 ( $<0.05)$, was marginally significant difference in responses. It also showed that a higher mean rank of woman (8.91) compared to men (5.50). It indicates that women are slightly less likely than men to have Englishspeaking friends.

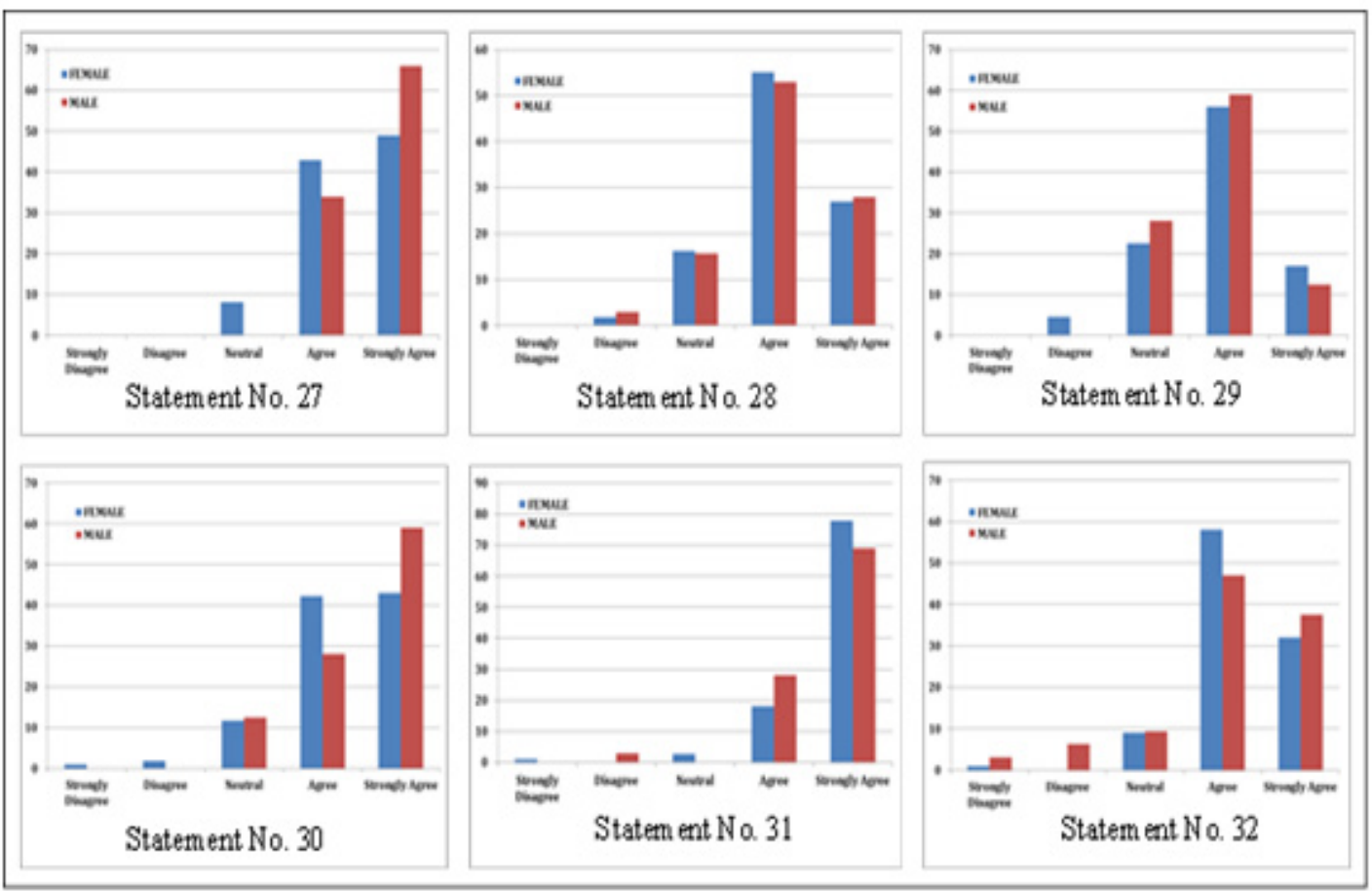

Figure 6 Charts of Statement 27-32 Responses 


\section{Discussion}

First of all, female and male are generally in a similar fashion of language learning beliefs in all categories of the questionnaire. Only 7 of 34 statements give significant difference in responses among them. In the first point, most respondents in a vast majority of percentage agree that children are easier than adult in learning language; that some people have special ability for it. These are consistent to the studies by Bernat and Llyod (2007) and Rieger (2009). Females and males in this study mostly believe that they have special ability in learning language. This differs from what Bernat and Llyod (2007) and Rieger (2009) found on their surveys. EFL students at Australian university neither agree nor disagree they have special ability in learning foreign language; meanwhile, Hungarian students do not believe that they have it.

Furthermore, most respondents agree that some languages are easier than others; that learning a new word, excellent pronunciation and practicing a lot are important part of learning foreign language. They also thought that learning language is different than other academic subjects; that practicing with audio visual aids is important. These are also similar with the research findings by Bernat and Lloyd (2007) and Rieger (2009).

Still consisted with Bernat and Llyod's results, most respondents believe and want to learn to speak English very well. They think English important for people in Indonesia and would like to have English-speaking friends. They learn English to have better job opportunities as well as to know native speaker better. However, Rieger (2009) found that EFL learners in Hungarian neither agree nor disagree whether they learn English to get to know native speaker better.

Like research findings by Bernat and Llyod (2007) and Rieger (2009), most respondents in this study do not think that people who are good at math or science are not good at learning foreign languages. Then a vast majority of respondents also disagree that you shouldn't say anything in English until you can say it correctly.

Regarding to English difficulty, research results by Bernat and Llyod (2007), Reiger (2009) and the present study are alike. The majority of respondents think English medium. However, opinions about how long it will take to speak it very well if one spends 1 hour/day differ among the three studies. Survey by Bernat and Lyod (2007) showed that it will take three to five years; on the other hand, research by Rieger (2009) showed that Hungarian respondents believe it will take much longer, 5 to 10 years. Meanwhile, Indonesian respondents consider learning English much easier; it will only take 1 to 2 years.

In the term of gender difference in responses, the present study showed that women are more likely to believe than men that they are better language learners. Then women are more likely to agree that people who speak more than one language are very intelligent as on Bernat and Llyod (2007). Nonetheless, it is different from EFL learners in Australian where women enjoy less in practicing English with native speakers; EFL female college-students in Indonesia are more likely to enjoy it.

From this survey, it is also found that woman are more likely to disagree that it is necessary to learn about
English speaking cultures to speak English and to believe that learning a new word is the most important part of learning language. Besides, women are more likely to believe that they will learn to speak English very well. However, males are more likely than women to have English-speaking friends. These results are not found on either Bernat and Llyod (2007) or Reiger (2009).

\section{CONCLUSION}

From the survey, it can be found several conclusions that female and male college-students mostly agree with the statements, some neutral options and disagreement. In short, females and males in this study respond in a similar fashion. In addition to the description of language learning beliefs, significant differences in responses also occur between males and females, 7 out of 34 statements on the questionnaire. It is found that women are more likely than men to believe that they are better language learners as well as women are more likely to agree that people who speak more than one language are very intelligent. Moreover, they are also more likely than men to enjoy practicing English with the native speaker.

Still related to gender and its significant differences, females and males differ significantly in beliefs. Women are more likely to disagree that it is necessary to learn about English speaking cultures to speak English and to believe that learning a new word is the most important part of learning language. Besides, women are more likely to believe that they will learn to speak English very well. However, males are more likely than women to have English-speaking friends.

Nevertheless, some weak points occurred when getting the representative data. Firstly, the ratio of the samples between females $(\mathrm{N}=111)$ and males $(\mathrm{N}=32)$ were not in balance or even. By increasing the ratio of samples in balance probably make the obtained data more representative. Secondly, the findings of present research only reveal language learners' beliefs about language learning with no consideration on their different cultural backgrounds, personality types, language competences and other individual factors. As a consequence, perhaps the results cannot be generalized for other foreign language situations even in Indonesia. For further research, it may explore language learning belief across different education level, cultural background as well as other stable individual factors such as personality types.

\section{REFERENCES}

Ariyoso. (2009). Uji Mann-Whitney U. Retrieved Feb 3, 2014 from http://statistik4life.blogspot. com/2009/12/uji-mann-whitney-u.html

Bernat, E., \& Llyod, R. (2007). Exploring the gender effect on EFL learners' belief about language learning. Australian Journal of Educational \& Developmental Psychology, 7, 79-91.

Coates, J. (2007). Gender. In C. Llamas, L. Mullany, \& P. Stockwell, The Routledge Companion to Sociolinguistics (pp. 62-68). New York: Routledge.

Fujiwara, T. (2011). Language learning beliefs of Thai EFL University students: Dimensional structure 
and cultural variations. Electronic Journal of Foreign Language Teaching, 8(1), 87-107.

Maftoon, P., \& Shakouri, N. (2013). Relationship between learners' beliefs system and the choice of language learning strategies: A critical study. International Journal of Research Studies in Language Learning, 2(2), 39-48.

Mesri, F. (2012). Exploring the gender effect on Iranian University Learners' beliefs to learn English. International Journal of Academic Research in Business and Social Sciences, 2(6), 98-106.

Moriam, Q. M. (2005). Speaking strategy use by the EFL students in Japan and Bangladesh. Journal of International Developmental and Coorporation, 12(1), 47-61.

Rieger, B. (2009). Exploring Gender and Target Language Effect on Hungarian EFL Learners' Belief about Language Learning. In J. Horvath, M. Nikolov, \& R. Lugossy, UPRT 2008: Emppirical Studies in English Applied Linguistics (pp. 29-42). Pecs: Lingua Franca Csoport.

Statistics of Your Live. (2010). Uji Wilcoxon. Retrieved Feb 3, 2014 from http://exponensial.wordpress. com/2010/05/13/uji-wilcoxon/ 